\title{
UPAYA MENINGKATKAN KEPERCAYAAN DIRI DAN KEMAMPUAN BERNALAR MATERI TRIGONOMETRI MELALUI DISCOVERY LEARNING BERBANTUAN LEMBAR AKTIVITAS SISWA(LAS) PADA SISWA KELAS X TGB-D SMK N 2 WONOGIRI
}

\author{
ENY MAILIANA INTARTININGSIH \\ SMK Negeri 2 Wonogiri, Wonogiri, Jawa Tengah
}

enymailiana@gmail.com

\begin{abstract}
ABSTRAK
Penelitian ini bertujuan untuk meningkatkan kepercayaan diri dan kemampuan bernalar materi Trigonometri melalui discovery learning berbantu lembar Aktivitas Siswa (LAS) bagi siswa kelas X TGB - D semester genap SMK N 2 Wonogiri. Hipotesis tindakan dalam penelitian ini yaitu penerapan metode discovery learning berbantuan Lembar Aktivitas Siswa (LAS) untuk meningkatkan kepercayaan diri, kemampuan bernalar dan hasil belajar siswa materi Trigonometri pada siswa kelas X TGB - D SMK N 2 Wonogiri. Hasil dari penelitian menunjukkan hal-hal sebagai berikut : peningkatan kepercayaan diri siswa dari prasiklus sebesar $53 \%$ ke siklus 2 sebesar $67 \%$, peningkatan kemampuan bernalar siswa dari prasiklus sebesar $34 \%$ ke siklus 2 sebesar $67 \%$, peningkatan hasil belajar siswa dari prasiklus sebesar $53 \%$ ke siklus 2 sebesar $79 \%$. Dari data tersebut diperoleh kesimpulan bahwa penerapan metode discovery learning berbantuan Lembar Aktivitas Siswa (LAS) dapat meningkatkan kepercayaan diri, kemampuan bernalar dan hasil belajar siswa X TGB-D SMK Negeri 2 Wonogiri. Hasil penelitian ini dapat digunakan sebagai salah satu alternatif pemikiran untuk meningkatkat kepercayaan diri siswa, kemampuan bernalar dalam proses belajar mengajar sehingga prestasi belajar dapat pula ditingkatkan.
\end{abstract}

Kata kunci : Model Discovery Learning, kepercayaan diri, kemampuan bernalar

\section{PENDAHULUAN}

Sikap siswa terhadap matematika merupakan salah satu bagian dalam karakteristik siswa yang tidak dapat diabaikan dalam pembelajaran matematika. Dalam pembelajaran matematika siswa terkesan kurang kepercayaan diri dalam mengemukakan ide atau jawabannya. Hal ini tampak pada perilaku siswa mengerjakan tugas tanpa kesadaran diri, siswa malu bertanya pada guru, siswa ragu dalam menjawab pertanyaan guru, siswa takut tampil di depan kelas, dan siswa masih bergantung pada teman atau guru. Hal ini ditunjukkan dengan ketika guru meminta siswa untuk menyelesaikan soal, beberapa siswa kebingungan dan kesulitan dalam menyelesaikan soal tersebut, sehingga soal dibiarkan begitu saja tanpa ada penyelesaian. Bahkan siswa terkesan cepat berputus asa ketika menemukan soal yang tidak sama dengan contohnya. siswa terlihat pasif dan kurang komunikatif dalam kegiatan belajar mengajar. Terkadang masih ada siswa yang menunggu hasil pekerjaan dari temannya, dan ada juga merasa takut atau malu menyelesaikan soal di depan temannya sendiri. Sebagian yang lain tidak dapat mengembangkan ketrampilan menyelesaikan soal pada penyelesaian soal yang berbeda dari apa yang telah dipelajari. Kondisi ini 
menggambarkan ketidakpercayaan siswa terhadap dirinya sendiri dalam menyelesaikan soal-soal matematika sehingga menyebabkan kemampuan bernalar menjadi tidak terasah.

Dari beberapa uraian di atas, guru dituntut untuk lebih kreatif dan profesional dalam memilih pendekatan pembelajaran yang sesuai dengan karakteristik siswa serta karakteristik materi yang akan diajarkan. Atas dasar pemikiran di atas penulis merancang penelitian tindakan kelas untuk meningkatkan kepercayaan diri, kemampuan bernalar dan hasil belajar materi Trigonometri melalui discovery learning berbantuan Lembar Aktivitas Siswa (LAS). Berdasarkan latar belakang masalah di atas dapat dirumuskan permasalahan sebagai berikut : Bagaimana penerapan metode discovery learning berbantuan Lembar Aktivitas Siswa (LAS) dapat meningkatkan kepercayaan diri, kemampuan bernalar dan hasil belajar pada materi Trigonometri bagi siswa kelas X TGB - D SMK Negeri 2 Wonogiri?

Adapun tujuan penelitian adalah untuk meningkatkan kepercayaan diri, kemampuan bernalar dan hasil belajar materi Trigonometri melalui discovery learning berbantuan lembar Aktivitas Siswa (LAS) bagi siswa kelas X TGB - D SMK N 2 Wonogiri. Manfaat penelitian ini adalah bagi siswa dapat meningkatkan kepercayaan diri dalam menyelesaikan soal-soal matematika khususnya materi Trigonometri, meningkatkan Kemampuan bernalar siswa dalam materi Trigonometri, mengembangkan kemampuan siswa dalam membangun pengetahuannya sendiri, mengembangkan kemampuan siswa untuk menyatakan pendapat dan gagasan sendiri. Bagi guru adalah untuk meningkatkan kemampuan guru dalam memecahkan masalah yang terjadi pada kegiatan belajar mengajar di kelasnya, menciptakan suasana belajar bermakna dan menyenangkan melalui pembelajaran dengan menggunakan discovery learning berbantuan Lembar Aktivitas Siswa (LAS), meningkatkan kolaborasi dengan sesama guru team teaching tentang Penelitian Tindakan Kelas, mendorong guru untuk melakukan penelitian, khususnya penelitian tindakan kelas, membantu guru dalam melakukan pengembangan keprofesian berkelanjutan

\section{METODE PENELITIAN}

Metode yang digunakan dalam penelitian ini adalah Penelitian tindakan kelas yang dilakukan di SMK Negeri 2 Wonogiri pada kelas X TGB - D Kompetensi Keahlian Teknik Gambar Bangunan dengan jumlah 34 siswa. Penelitian dilaksanakan dari tahap persiapan hingga pelaporan selama 6 bulan, dimulai pada bulan April 2017 hingga bulan September 2017, dengan rincian setiap minggu 1 kali tatap muka (4 jam pelajaran). Tahap perencanaan pada bulan April 2017, pelaksanaan penelitian minggu terakhir bulan April 2017 hingga bulan Mei 2017. Sedangkan tahap pelaporan sampai dengan bulan Juli sampai September 2017

\section{HASIL DAN PEMBAHASAN}

\section{Deskripsi Awal}

Pembelajaran pada kondisi awal ini dilaksanakan pada hari Rabu, 26 April 2017 dengan materi "Aturan Sinus dan Cosinus". Berdasarkan hasil observasi dalam pembelajaran matematika siswa terkesan kurang kepercayaan dirinya yaitu sebesar 
$53 \%$ dengan rincian presentase indikator berani presentasi/mengerjakan di depan kelas sebesar $60 \%$. Berani berpendapt, bertanya, atau menjawab pertanyaan sebesar 46\%. Berpendapat atau melakukan kegiatan tanpa ragu-ragu sebesar 53\%. Mampu membuat keputusan dengan cepat sebesar 56\% dan tidak mudah putus asa sebesar $50 \%$. Kemampuan bernalar pada kondisi awal masih tergolong rendah. Hal ini terlihat dari dari nilai ulangan harian materi perbandingan sisi pada segitiga siku-siku khususnya soal-soal tentang penalaran siswa masih banyak yang belum benar atau mendekati benar. Siswa belum mampu menyajikan pernyataan matematika secara lisan, tulisan atau grafik, menyajikan soal dalam bahasa matematika, melakukan manipulasi matematika, mengajukan dugaan, menemukan pola/sifat dari situasi matematis yang ada dan memeriksa kesahihan suatu argumen.

Data hasil belajar siswa pada kondisi awal diperoleh data, dari 34 siswa yang mengikuti tes sebanyak 16 siswa atau $47 \%$ tidak tuntas (nilai dibawah KKM sebesar 60) jadi hanya 18 siswa atau $53 \%$ yang mencapai nilai KKM, dengan perolehan nilai tertinggi 80 dan nilai terendah 35 sedangkan nilai rata-rata kelas 59.

\section{SIKLUS 1}

\section{Deskripsi Data}

Pembelajaran pada siklus 1 ini dilaksanakan 2 pertemuan. Pertemuan pertama pada hari Rabu, 3 Mei 2017 dengan materi " Grafik fungsi sinus". Sedangkan pertemuan kedua pada hari Rabu, 17 Mei 2017 dengan materi pembelajaran "Grafik fungsi sinus". Pembelajaran pada siklus 1 ini sudah menggunakan pembelajaran Discovery Learning berbantuan Lembar Aktivitas Siswa yang masih sederhana.

\section{Deskripsi Kepercayaan Diri}

Berdasarkan hasil observasi siklus 1 dalam pembelajaran matematika siswa mulai menunjukkan kepercayaan dirinya. Beberapa anak mulai berani untuk maju mengerjakan soal di depan kelas. Mereka mencoba untuk mengerjakan soal di depan kelas sesuai dengan kemampuan yang dimilikinya. Kegiatan berdiskusi secara berkelompok dengan menggunakan media Lembar Aktivitas siswa (LAS) memancing siswa untuk berani berpendapat, bertanya, maupun menjawab pertanyaan. Pada LAS terdapat petunjuk mengerjakan yang memberikan stimulus kepada siswa untuk menjawab pertanyaan dengan melakukan tanya-jawab dengan anggota kelompoknya. Pada saat pembelajaran metode yang digunakan oleh guru tidak menggunakan metode ceramah saja, siswa mulai dilibatkan dalam menemukan rumus-rumus matematika, sehingga siswa melakukan sendiri pengalaman dalam menggambar grafik sinus. Hal ini menjadikan siswa lebih mudah menjawab soal-soal grafik fungsi rigonometri. 
Tabel 4.4. Data Observasi Kepercayaan diri

\begin{tabular}{|c|l|c|}
\hline No & \multicolumn{1}{|c|}{ Indikator } & $\%$ \\
\hline 1 & Berani presentasi/mengerjakan di depan kelas & 65 \\
\hline 2 & Berani berpendapat, bertanya, atau menjawab pertanyaan & 60 \\
\hline 3 & Berpendapat atau melakukan kegiatan tanpa ragu-ragu & 60 \\
\hline 4 & Mampu membuat keputusan dengan cepat & 60 \\
\hline 5 & Tidak mudah putus asa/pantang menyerah & 57 \\
\hline \multicolumn{2}{|l|}{ Presentase Kepercayaan diri } & 60 \\
\hline
\end{tabular}

\section{Deskripsi Kemampuan Bernalar}

Pada siklus 1 guru mengajarkan bagaimana cara menggambar grafik fungsi $y=$ $\sin x$ pada bidang koordinat cartesius. Penalaran induktif dalam menggambar grafik fungsi trigonometri ditunjukkan dengan mencari titik-titik koordinat yang dilalui grafik dengan mensubstitusikan sudut istimewa ke dalam variabel $x$ pada rumus fungsi trigonometri yang dimaksud. Siswa bersama kelompoknya kemudian menggambar grafik fungsi trigonometri yang diminta di LAS.

\section{Tabel 4.6. Data Kemampuan bernalar siswa}

\begin{tabular}{|c|l|c|}
\hline No & \multicolumn{1}{|c|}{ Indikator } & $\%$ \\
\hline 1 & Menyajikan pernyataan matematika secara lisan, tulisan, atau grafik & 74 \\
\hline 2 & Melakukan manipulasi Matematika & 73 \\
\hline 3 & Menemukan pola atau sifat dari situasi matematis yang ada & 59 \\
\hline 4 & Mengajukan dugaan & 50 \\
\hline 5 & Memeriksa kesahihan suatu argumen & 38 \\
\hline \multicolumn{2}{|c|}{ Presentase Kemampuan bernalar } & 59 \\
\hline
\end{tabular}

\section{Deskripsi Hasil Belajar}

Pada siklus 1 diperoleh data, dari 34 siswa yang mengikuti tes sebanyak 9 siswa atau 26\% tidak tuntas (nilai dibawah KKM sebesar 60) sedangkan sebanyak 25 siswa atau $74 \%$ mencapai nilai KKM, dengan perolehan nilai tertinggi 100 dan nilai terendah 40 sedangkan nilai rata-rata kelas 66. 


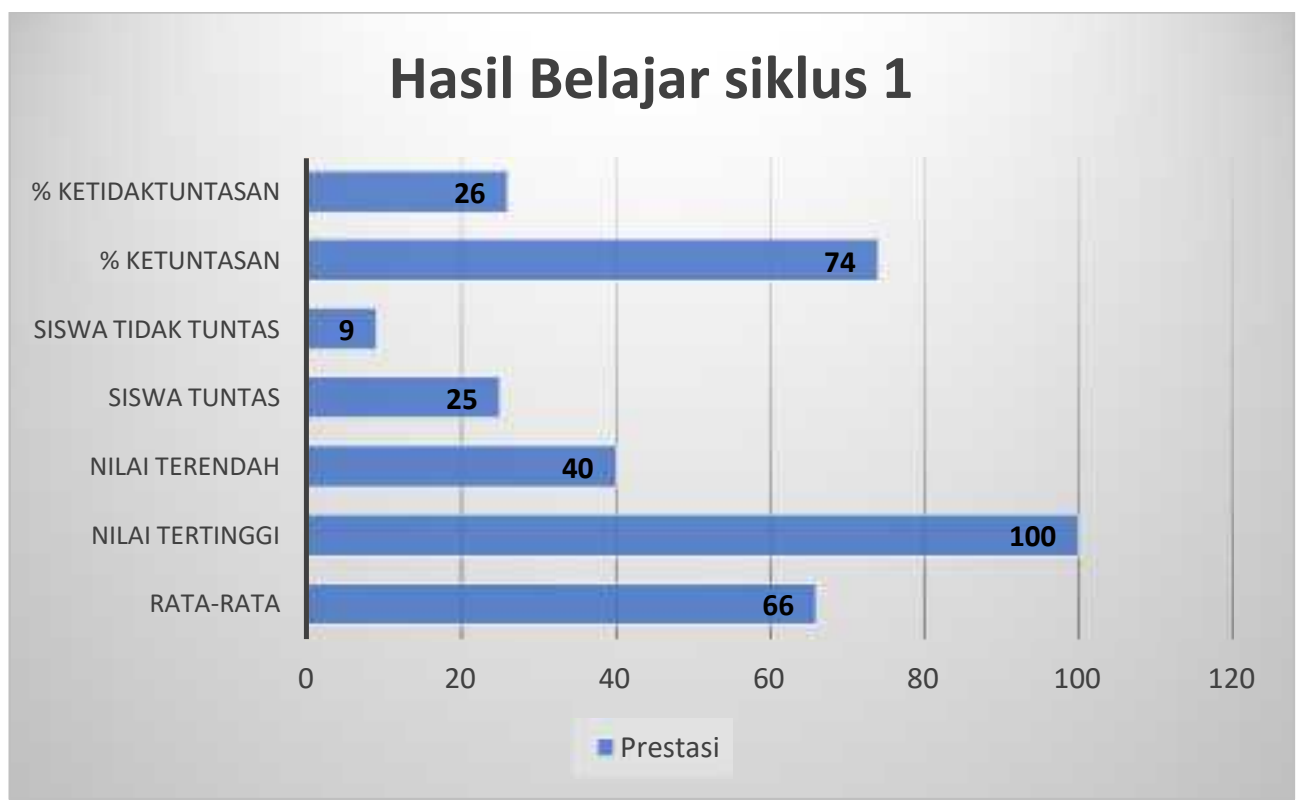

Gambar 4.7. Diagram hasil belajar

\section{Refleksi}

\section{Refleksi Kepercayaan diri}

Adanya siswa yang kurang dalam memahami materi dan tidak mau bertanya kepada teman dalam satu kelompok dapat menghambat jalannya proses pembelajaran. Guru meminta siswa yang kurang untuk mencari penjelasan kepada temannya mengenai masalah yang ada pada LAS sehingga semua siswa aktif dalam mempelajari materi. Siswa kesulitan menentukan titik-titik koordinat yang diperlukan dalam menggambar grafik, sehingga diperlukan petunjuk khusus dari guru. Kurangnya umpan balik yang konstruktif dalam pembelajaran yang dapat meningkatkan kepercayaan diri siswa.

\section{Refleksi Kemampuan Bernalar}

Siswa masih kaku dengan pembelajaran dengan menggunakan metode pembelajaran discovery learning dengan berbantuan Lembar Aktivitas Siswa (LAS). Siswa yang sudah terbiasa menerima semua hal dari guru beralih berusaha menemukan sendiri materi-materi yang dipelajari dengan mengikuti petunjuk-petunjuk yang diberikan. Pembagian Lembar Aktivitas Siswa (LAS) hendaknya persiswa supaya siswa tidak bergiliran untuk membaca LAS tersebut sehingga siswa bebas menjawab soal tersebut dengan mandiri untuk didiskusikan dikelompoknya. Pentunjuk-petunjuk yang diberikan guru dalam rangka untuk mengasah kemampuan siswa dalam menemukan pola, mengajukan dugaan dan memeriksa kesahihan suatu argumen masih kurang, sehingga hasilnya juga kurang maksimal.

Karena pada tahap siklus 1 belum terpenuhinya target sesuai indikator maka perlu dilakukan perbaikan lagi pada siklus berikutnya. Hal yang perlu dilakukan diantaranya mengurangi perilaku siswa yang tidak relevan dengan pembelajaran, 
contohnya: mengganggu kegiatan siswa lainnya, berdiam diri ditempat duduknya tanpa berupaya menyelesaikan tugas yang diberikan, keluar masuk ruangan kelas selama kegiatan pembelajaran berlangsung, melakukan kegiatan lain yang tidak terkait dengan tugas yang diberikan, dengan mengaktifkan siswa yang kurang mampu, lebih memotivasi siswa untuk meningkatkan kepercayaan dirinya sehingga tidak mudah putus asa ketika menghadapi soal-soal yang sulit.

\section{Siklus 2}

\section{Diskripsi Kepercayaan diri}

Pada pembelajaran siklus 2 kepercayaan diri siswa dalam pembelajaran Matematika mengalami peningkatan dari siklus 1. Hal ini ditunjukkan semakin banyaknya siswa yang berani mengerjakan soal di depan kelas. Pada saat pembelajaran media yang dipakai juga menggunakan LAS (Lembar Aktivitas Siswa) yang sudah tertata rapi yang digunakan membantu pemahaman siswa sehingga siswa dipermudah dalam menemukan grafik fungsi cosinus. Pembagian kelompok siswa yang awalnya dibagi menjadi kelompok besar yaitu 5 kelompok, pada siklus 2 dibagi menjadi 8 kelompok. Sehingga setiap anggota kelompok harus berusaha memahami materi yang dipelajari dan memahamkan teman satu kelompoknya. Dalam kegiatan diskusi maupun saat tes, daya juang siswa mulai meningkat, mereka tidak mudah menyerah atau cepat putus asa ketika mengerjakan soal-soal. Siswa yang pada siklus 1 masih mencontek pekerjaan temannya sudah mulai berkurang, mereka mencoba untuk mendapatkan jawabannya sendiri.

Tabel 4.5. Data observasi kepercayaan

\begin{tabular}{|c|l|c|}
\hline No & \multicolumn{1}{|c|}{ Indikator } & $\%$ \\
\hline 1 & Berani presentasi/mengerjakan di depan kelas & 74 \\
\hline 2 & Berani berpendapat, bertanya, atau menjawab pertanyaan & 67 \\
\hline 3 & Berpendapat atau melakukan kegiatan tanpa ragu-ragu & 66 \\
\hline 4 & Mampu membuat keputusan dengan cepat & 63 \\
\hline 5 & Tidak mudah putus asa/pantang menyerah & 66 \\
\hline \multicolumn{2}{|l|}{ Presentase Kepercayaan diri } & 67 \\
\hline
\end{tabular}

\section{Deskripsi Kemampuan Bernalar}

Siswa mulai mampu menyajikan pernyataan matematika secara lisan, tulisan, atau grafik sebesar 79\%. Memanipulasi matematika dengan menentukan titik-titik puncak dan titik potong dengan sumbu $\mathrm{X}$ yang dapat membantu membuat grafik fungsi Trigonometri sebesar 76\%. Siswa mampu menemukan pola dari masing-masing gambar grafik yang dikaitkan dengan rumus fungsinya kemudian dibuat hubungan antar keduanya yaitu sebesar $67 \%$. Siswa mampu mengajukan dugaan dari hubungan yang ia dapatkan dari bentuk grafik dan fungsi trigonometri yang ada sebesar $61 \%$. Memeriksa kesahihan suatu argumen sebesar 52\%. 


\section{Deskripsi Hasil Belajar}

Pada siklus 2 diperoleh data, dari 34 siswa yang mengikuti tes sebanyak 7 siswa atau $21 \%$ tidak tuntas (nilai dibawah KKM sebesar 60) sedangkan sebanyak 27 siswa atau $79 \%$ mencapai nilai KKM, dengan perolehan nilai tertinggi 90 dan nilai terendah 36 sedangkan nilai rata-rata kelas 70 .

Dari uraian data di atas menunjukkan bahwa pemahaman siswa terhadap materi ada peningkatan, terbukti dari hasil belajar siswa mengalami peningkatan, yaitu sebesar $5 \%$. Dalam proses pembelajaran dengan Discovery Learning siswa mencari dan menemukan solusi dari permasalahan yang muncul sehingga mereka mampu mengkontruksi sendiri pengetahuannya.

\section{HASIL BELAJAR SISWA SIKLUS 2}

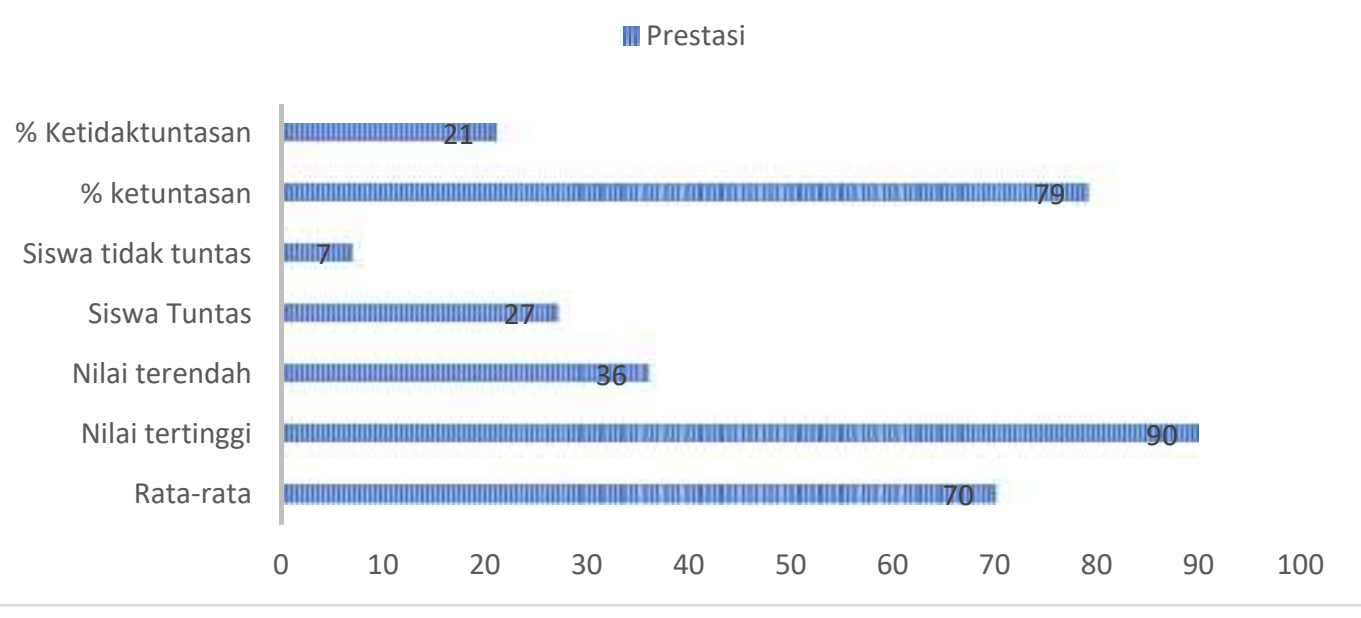

Gambar 4.16. Diagram hasil belajar

\section{Refleksi siklus 2}

\section{Refleksi Kepercayaan Diri}

Dari uraian data tersebut menunjukkan bahwa terdapat peningkatan persentase kepercayaan diri siswa dari $53 \%$ pada prasiklus menjadi $60 \%$ pada siklus 1 dan meningkat menjadi $67 \%$ pada siklus 2 .

Hasil observasi kepercayaan diri siswa tersebut juga diperkuat dengan peningkatan hasil angket siswa yang menunjukkan indikator inisiatif, yaitu keberanian bertanya, berpendapat, menjawab pertanyaan, dan bersemangat dalam pembelajaran sebesar $60 \%$ pada siklus 1 meningkat menjadi $70 \%$ pada siklus 2 . Siswa mampu mengerjakan soal-soal grafik trigonometri, tidak mudah cemas jika mendapati soalsoal sulit, mengerjakan soal dengan senang hati, dan berani tampil ke depan yang merupakan bagian dari indikator optimis sebesar $57 \%$ pada siklus 1 menjadi $70 \%$ pada siklus 2. Pengalaman-pengalaman dalam pembelajaran menjadikan siswa mulai tidak bergantung pada orang lain dalam mengerjakan soal, tidak mencontek saat ulangan yang merupakan bagian dari indikator mandiri sebesar 59\% pada siklus 1 menjadi $64 \%$ 
pada siklus 2. Pada indikator tidak mudah putus asa/pantang menyerah. sebesar $56 \%$ pada siklus 1 meningkat sebesar $65 \%$ pada siklus 2 .

Dari uraian data angket siswa menunjukkan bahwa terdapat peningkatan persentase kepercayaan diri siswa dari 58\% menjadi $67 \%$ tidak beda jauh dengan hasil data observasi.

Refleksi pada siklus 2, masih ada siswa yang tidak bertanya mengenai hal-hal yang kurang jelas pada saat diskusi, tidak mencatat hasil pengamatan dengan mengorganisasi informasi yang belum menemukan jawaban masalah secara mandiri dikelompoknya, dan melalukan generalisasi dan kesimpulan suatu masalah dari hasil diskusi sehingga menjadikan kepercayaan diri siswa belum maksimal berkembang.

\section{Refleksi Kemampuan Bernalar}

Refleksi pada siklus 2, siswa mulai terbiasa dengan pembelajaran menggunakan model pembelajaran discovery learning dengan berbantuan Lembar Aktivitas Siswa (LAS). Siswa yang sudah terbiasa berusaha menemukan sendiri materi-materi yang dipelajari dengan mengikuti petunjuk-petunjuk yang diberikan. Pentunjuk-petunjuk yang diberikan guru dalam rangka untuk mengasah kemampuan siswa dalam menemukan pola, mengajukan dugaan dan memeriksa kesahihan suatu argumen sudah ada perkembangan.

\section{Refleksi Hasil Belajar}

Pada siklus 1 diperoleh data, dari 34 siswa yang mengikuti tes sebanyak 9 siswa atau 26\% tidak tuntas (nilai dibawah KKM sebesar 60) sedangkan sebanyak 25 siswa atau $74 \%$ mencapai nilai KKM, dengan perolehan nilai tertinggi 100 dan nilai terendah 40 sedangkan nilai rata-rata kelas 66. Sedangkan pada siklus 2 diperoleh data, dari 34 siswa yang mengikuti tes sebanyak 7 siswa atau $21 \%$ tidak tuntas (nilai dibawah KKM sebesar 60) sedangkan sebanyak 27 siswa atau $79 \%$ mencapai nilai KKM, dengan perolehan nilai tertinggi 90 dan nilai terendah 36 sedangkan nilai rata-rata kelas 70 .

Dari uraian data di atas dapat disimpulkan bahwa terjadi peningkatan hasil belajar sebesar dari $74 \%$ menjadi $79 \%$ atau sebesar $5 \%$.

\section{Pembahasan/Diskusi}

\section{Pembahasan Kepercayaan diri Siswa}

Pada prasiklus, kepercayaan diri siswa sebesar $53 \%$ sedangkan pada siklus 2 kepercayaan diri siswa sebesar $67 \%$ maka dengan penerapan metode Discovery Learning berbantuan Lembar aktivitas Siswa (LAS) dapat meningkatkan kepercayaan diri siswa.

Melalui pembelajaran dengan metode Discovery Learning berbantuan Lembar Aktivitas Siswa (LAS) dapat meningkatkan kepercayaan diri siswa X TGB-D SMK Negeri 2 Wonogiri semester genap tahun pelajaran 2016/2017 dari prasiklus sebesar $53 \%$ ke siklus 2 sebesar $67 \%$.

Besarnya peningkatan kepercayaan diri siswa dengan penerapan metode Discovery Learning berbantuan Lembar Aktivitas Siswa (LAS) bagi siswa X TGB-D SMK Negeri 2 Wonogiri semester genap tahun pelajaran 2016/2017 adalah $14 \%$. 


\section{Pembahasan Kemampuan Bernalar}

Pada prasiklus kemampuan bernalar siswa sebesar $34 \%$ sedangkan pada siklus 2 ketuntasan belajar siswa mencapai $67 \%$ maka dengan penerapan metode Discovery Learning berbantuan Lembar Aktivitas Siswa dapat meningkatkan kemampuan bernalar siswa.

Melalui pembelajaran dengan metode Discovery Learning berbantuan Lembar Aktivitas Siswa (LAS) dapat meningkatkan kemampuan bernalar bagi siswa X TGBD SMK Negeri 2 Wonogiri semester genap tahun pelajaran 2016/2017 dari prasiklus sebesar $34 \%$ ke siklus 2 sebesar $67 \%$.

Besarnya peningkatan kemampuan bernalar siswa melalui pembelajaran dengan metode Discovery Learning berbantuan Lembar Aktivitas Siswa (LAS) bagi siswa X TGB-D SMK Negeri 2 Wonogiri semester genap tahun pelajaran 2016/2017 adalah $33 \%$.

\section{Pembahasan Hasil Belajar}

Pada prasiklus ketuntasan belajar siswa sebesar $53 \%$ sedangkan pada siklus 2 ketuntasan belajar siswa mencapai $79 \%$ maka dengan penerapan metode Discovery Learning berbantuan Lembar Aktivitas Siswa dapat meningkatkan hasil belajar siswa. Melalui pembelajaran dengan metode Discovery Learning berbantuan Lembar Aktivitas Siswa dapat meningkatkan hasil belajar bagi siswa X TGB-D SMK Negeri 2 Wonogiri semester genap tahun pelajaran 2016/2017 dari prasiklus sebesar $53 \%$ ke siklus 2 sebesar $79 \%$.

Besarnya peningkatan hasil belajar siswa melalui pembelajaran dengan metode Discovery Learning berbantuan Lembar Aktivitas Siswa (LAS) bagi siswa X TGB-D SMK Negeri 2 Wonogiri semester genap tahun pelajaran 2016/2017 adalah $26 \%$.

\section{KESIMPULAN}

Berdasarkan hipotesis tindakan dalam penelitian ini yaitu penerapan metode discovery learning berbantuan Lembar Aktivitas Siswa (LAS) dapat meningkatkan kepercayaan diri, kemampuan bernalar dan hasil belajar siswa kelas X TGB - D SMK N 2 Wonogiri sedangkan hasil tindakan menunjukkan peningkatan kepercayaan diri siswa dari prasiklus sebesar $53 \%$ ke siklus 2 sebesar $67 \%$, peningkatan kemampuan bernalar siswa dari prasiklus sebesar $34 \%$ ke siklus 2 sebesar $67 \%$, peningkatan hasil belajar siswa dari prasiklus sebesar $53 \%$ ke siklus 2 sebesar $79 \%$, maka dapat disimpulkan bahwa melalui penerapan metode discovery learning berbantuan Lembar Aktivitas Siswa (LAS) dapat meningkatkan kepercayaan diri, kemampuan bernalar dan hasil belajar siswa X TGB-D SMK Negeri 2 Wonogiri semester genap tahun pelajaran 2016/2017.

Besarnya peningkatan kepercayaan diri siswa, kemampuan bernalar dan hasil belajar dengan penerapan metode Discovery Learning berbantuan Lembar Aktivitas Siswa (LAS) bagi siswa X TGB-D SMK Negeri 2 Wonogiri semester genap tahun pelajaran 2016/2017 berturut-turut $14 \%, 33 \%$, dan $26 \%$.

Saran yang dapat disampaikan adalah (1). Dalam rangka meningkatkan kepercayaan diri siswa, kemampuan bernalar dan hasil belajar siswa dalam pelajaran 
Matematika dapat menggunakan alternatif model pembelajaran yaitu dengan menerapkan model discovery learning berbantuan Lembar aktivitas siswa (LAS). (2) Dalam rangka meningkatkan kemampuan guru dalam memecahkan masalah yang terjadi pada kegiatan belajar mengajar di kelasnya, menciptakan suasana belajar bermakna dan menyenangkan, guru dapat menerapkan pembelajaran dengan menggunakan discovery learning berbantu Lembar Aktivitas Siswa (LAS).

\section{DAFTAR PUSTAKA}

Adhar, Leo. (2012). Pembelajaran Matdematika dengan Metode Penemuan Terbimbing untuk Meningkatkan Kemampuan Representatif dan Pemecahan Masalah Matematis Siswa SMP. Jurnal Penelitian Pendidikan | Vol. 13 No. 2 Oktober 2012. http://jurnal.upi.edu/file/Leo_Adhar.pdf. (diakses tanggal 1 Maret 2017 pukul 11.13 WIB)

Ahmad, Habriah. (2015). Peningkatan Kemampuan Penalaran Matematika Materi Trigonometri melalui Penerapan Model Pembelajaran Discovery learning dengan Pendekatan Saintifik pada Kelas X SMA Negeri 11 Makasar. Jurnal Daya Matematis, Volume 3. No. 3 November 2015. http://ojs.unm.ac.id/index.php/JDM/article/download/1697/pdf_10 • (diakses tanggal 1 maret 2017 pukul 11.13 WIB)

Lestari, E.K., Yudhanegara, R.M. (2015). Penelitian Pendidikan Matematika. Bandung: PT Refika Aditama.

Mayangsari, Umi. (2013). Peningkatan Sikap Percaya Diri siswa melalui Startegi Pembelajaran Inkuiri Terbimbing Pada Mata pelajaran IPA Kelas VB Sekolah Dasar Negeri

Tukangan. http://eprints.uny.ac.id/15930/1/Skripsi_Umi\%20Mayangsari_09108241010.pd f. ( diakses tanggal 8 April 2017 pukul 11:15) 